\title{
Clinical Profile and CT-Chest Patterns of 56 Patients with Covid-19 Pneumonia
}

\author{
Olla A M Ibrahim, Enas M Alhaen, Walid A S Mohmmed and Wadyan M A \\ Salh
}

Radiology department, Faculty of Medicine, Omar Al Mukhtar University Albayda City, Libya

Received: 29 November 2020 / Accepted: 30 December 2020

Doi: https://doi.org/10.54172/mjsc.v35i4.334

\begin{abstract}
Since the COVID-19 pandemic was announced, the concern of radiologists and physicians regarding its diagnosis has been profoundly raised. The primary reference for confirming COVID-19 pneumonia relies on reverse transcriptase-polymerase chain reaction (RTPCR) testing, where the subject of availability, false negative-rates, practice dependency, and time-consumption, made computed tomography (CT) more superior in Covid-19 pneumonia diagnosis, which was the situation in Al-Bayda-citylLibya. The first local case in Al-Baydacity was reported on 30 July 2020, followed by a dramatic surge in the number of cases, which necessitated the recognition of main clinical features and CT-patterns of COVID-19 to facilitate rapid diagnosis. The aim of study: Describe the clinical features and the CT-chest patterns of COVID-19 pneumonia among the studied population. A descriptive case series study was conducted in the central hospital of Al-Bayda city/Libya from 11 August to 21 September 2020, which involved 56 patients (31 females and 25 males). Patients' ages ranged from 28-88 years $(62.79 \pm 11.3)$. Non-contrast CT-chest was performed on all patients. The main patients' complaints were fever $94.6 \%$, dyspnea $89.3 \%$, and cough $85.7 \%$. The most common CT pattern among the studied cases was ground-glass opacities found in $100 \%$ of patients, followed by vascular thickening $88 \%$, consolidative lesion $71.4 \%$, crazy-paving pattern $57 \%$, vacuolar sign $57.1 \%$, architecture distortion $40 \%$, halo sign $34 \%$, reverse halo sign $34.5 \%$, and traction-bronchiectasis $16 \%$ of the studied cases. Finally, recognition of CTchest patterns of Covid-19 pneumonia plays a significant role in early detection, and therefore isolation and management of the disease. The findings of this study can be used as a baseline for further research in the future.
\end{abstract}

Keywords: Covid19 Pneumonia; Covid-19; Covid-19 Libya; Chest CT; Ground-Glass Opacity (GOO).

\section{INTRODUCTION}

COVID-19 is an emerging global health problem caused by a novel coronavirus named severe acute respiratory syndrome coronavirus 2 (SARS-Cov-2). It is the seventh known coronavirus to infect humans, first noticed in December $2019 \mathrm{Wu}$ han $\backslash$ China. The World Health Organization (WHO) declared COVID-19 to be pandemic in March 2020. (Zheng 2020; Kim et al.
2020; Bernheim et al. 2020). As of $17^{\text {th }}$ November 2020 , a total of $54,771,888$ cases of COVID-19 have been confirmed, including 1,324,249 deaths (WHO, 2020a). Since diagnosing the first documented local transmission case of COVID-19 in Al Bayda city $\backslash$ Libya on 30 th July 2020 , the radiology department was overwhelmed by patients with typical COVID-19 symptoms with peculiar patterns in computerized tomography (CT) scans of the chest with an increased

*Corresponding Author: Olla A M Ibrahim Dr_all2000@yahoo.com, Radiology department, Faculty of Medicine, Omar Al Mukhtar University Albayda City, Libya 
death toll for cases with chest infections mainly due to viral pneumonia (Ibrahim, 2020). The clinical symptoms of COVID-19 range from asymptomatic to mild (lowgradelhigh fever, fatigue, dry cough, nasal congestion, diarrhea, and slight weakness with or without pneumonia), rarely a runny nose; to a severe form, characterized by dyspnea and/or hypoxemia that can quickly progress to respiratory distress, septic shock, uncorrectable metabolic acidosis, and coagulation disorders (Carotti et al.2020). The standard of reference for confirming COVID19 pneumonia relies on reverse transcriptase polymerase chain reaction (RT-PCR) tests. However, availability of (RT-PCR) in an emergency setting, a high rate of falsenegatives, low sensitivity (only 30-60\%), reliance on viral loads, time of sampling, and time consumption, made CT chest complementary and even superior in diagnosing COVID-19 in asymptomatic patients and symptomatic patients with an average of 5 days before an (RT-PCR) test becomes positive. In addition, some literature emphasizes the pivotal role of $\mathrm{CT}$ in the diagnosis of Covid-19 with 98\% sensitivity (Hani et al .2020; Carotti et al. 2020, Fang et al. 2020). Furthermore, some studies have recommended the usage of chest CT scans as a primary screening or diagnostic tool in epidemic areas (Ai et al. 2020).

Chest CT has high precision and can be used as a standard technique for COVID-19 diagnosis. The usage of chest $\mathrm{CT}$ for the diagnosis of viral pneumonia enables patients with suspected infection of COVID-19 to be isolated and managed in time for improvement, and therefore, optimize patient management (Li \& Xia 2020). The most common feature of covid-19 is bilateral ground-glass opacities (GGO), typically with a peripheral and subpleural distribution, consolidation, crazypaving pattern, vascular thickening, traction bronchiectasis, and reticular pattern (Zheng et al 2020; Bernheim et al 2020; Sabri et al 2020).
According to WHO guideline (2020b) "For symptomatic patients with suspected COVID19, using chest imaging for the diagnostic workup of COVID-19 when: (1) RT-PCR testing is not available; (2) RT-PCR testing is available, but results are delayed; and (3) initial RT-PCR testing is negative, but with high clinical suspicion of COVID-19" which is the situation in Al-Bayda city, RT-PCR is not available. Therefore, CT is used in the diagnostic workup.

This paper aims to describe the common CT patterns of covid-19 in Albayda as there is a growing need for local radiologists and physicians to be familiar with the covid-19 features in CT. In addition, comparing the result of this research with other regional and international findings.

\section{MATERIAL AND METHODS}

This descriptive case series study was conducted from $11^{\text {th }}$ August 2020 to $21^{\text {st }}$ September 2020. The ethical approval form to conduct the study was obtained from the radiology department at the central hospital Al Bayda city. The number of participants reviewed was 56. Patients who met the inclusion criteria based on the WHO criteria for covid-19 diagnosis by CT were included (WHO 2020b). The scans were performed using an FCT Speedia HD Fujifilm 64-MDCT scanner. The scout was taken in the supine position during holding of breath in full inspiration. The following parameters were used; $120 \mathrm{kV}, 5 \mathrm{~mm}$ beam collimation, 1.58 pitch, 0 gantry tilt, and the FOV (347-500) depending on the patient's size. The scans covered the whole thorax from the root of the neck to below the diaphragm. No intravenous contrast had been administered. Following acquisition, the images were reported by two radiologists.

Data regarding symptoms were collected either directly from patients or medical records during the scan. Data was filled manually in 
special paper forms; then entered into the computer system and analyzed using the Statistical Package of Social Science Software program, version 24 (IBM Corp).

\section{RESULTS}

This is a descriptive case series study that involved 56 patients, $31(55.4 \%)$ females, and $25(44.6 \%)$ males. Their ages range from 28 88 years $(62.79 \pm 11.3) .31(55.4 \%)$ were inpatient, while $25(44.6 \%)$ were out-patient.

The mean duration of symptoms was $8.6 \pm 19$ days. The most common symptoms among the studied patients were fever, dyspnea and cough, with $94.6 \%, 89.3 \%$, and $85.7 \%$ respectively. While headaches happened in two-thirds of them, and only $10 \%$ of complaints were vomiting and diarrhea (Table-1).

Table-(1): The percentage of symptoms among the studied population

\begin{tabular}{ccc}
\hline \hline Symptoms & $\begin{array}{c}\text { Number of pa- } \\
\text { tients }\end{array}$ & Percentage \\
\hline Fever & 53 & 94.6 \\
Dyspnea & 50 & 89.3 \\
Cough & 48 & 85.7 \\
Headache & 32 & 57.1 \\
Sweating & 30 & 53.3 \\
Sore throat & 25 & 44.6 \\
$\begin{array}{c}\text { Vomiting \& Diar- } \\
\text { rhea }\end{array}$ & 10 & 17.9 \\
\hline \hline
\end{tabular}

The majority of patients $(80 \%)$ had different comorbidities. $69.6 \%$ were diabetic, and $53.6 \%$ were hypertensive. Interestingly, nearly a quarter were both diabetic and hypertensive, which is the same fraction for those who were diagnosed with triple diseases (diabetes, hypertension, and heart disease). $20 \%$ of patients had no chronic illness (Table-2).
Table(2): The percentages of comorbidities among the studied patient.

\begin{tabular}{|c|c|c|}
\hline \hline Comorbidity & $\begin{array}{c}\text { Number of } \\
\text { Patients }\end{array}$ & Percentage \\
\hline $\begin{array}{c}\text { No chronic } \\
\text { illness }\end{array}$ & 11 & 19.6 \\
\hline Diabetes & 39 & 69.9 \\
\hline Hypertension & 30 & 53.6 \\
\hline Heart Disease & 13 & 23.3 \\
\hline Others & 2 & 7.1 \\
\hline \hline
\end{tabular}

The CT pattern of the studied cases: Regarding lobe involvements, all lobes were involved in $76.8 \% \quad(43 \backslash 56)$ of participants, while $10 \%(6 \backslash 56)$ of patients showed the involvement of all lobes with sparing of lingula segment. In addition, in $98.2 \%(55 \backslash 56)$ both lungs were affected.

In regard to the pattern of lung lesions among the studied patients, ground-glass opacities were found in $100 \%(56 \backslash 56)$ of patients, followed by vascular thickening detected in almost $88 \%$ (49\56). While Crazy paving pattern was found in more than half $(57 \%)$ of the studied population. Consolidative lesions appeared in the majority of studied cases $71.4 \%$. Vacuolar sign, halo sign, and reverse halo sign found in $57.1 \%(32 \backslash 56), 34 \%$ (19\56), and $34.5 \%(19 \backslash 56)$ of studied patients respectively (Table-3).

Table (3): The percentages of the different patterns of lung lesions among studied population

\begin{tabular}{ccc}
\hline \hline CT-pattern & $\begin{array}{c}\text { Number of } \\
\text { patients }\end{array}$ & Percentage (\%) \\
\hline $\begin{array}{c}\text { Ground-glass } \\
\text { opacity }\end{array}$ & 56 & 100 \\
$\begin{array}{c}\text { Vascular thicken- } \\
\text { ing }\end{array}$ & 49 & 87.5 \\
Consolidation & 40 & 71.4 \\
Crazy paving & 32 & 57.1 \\
Vacuolar sign & 32 & 57.1 \\
Halo sign & 19 & 34 \\
Revers halo sign & 19 & 34 \\
Architecture dis- & 19 & 34 \\
tortion & & 16 \\
Tractional- & 9 & \\
bronchiectasis & 9 & \\
\hline \hline
\end{tabular}


The percentages of architecture distortion and tractional-bronchiectasis were found in $40 \%$ (19\56), and 16\% (9\56) respectively. Some examples of common CT patterns are shown in (figures: 1,2 , and 3).

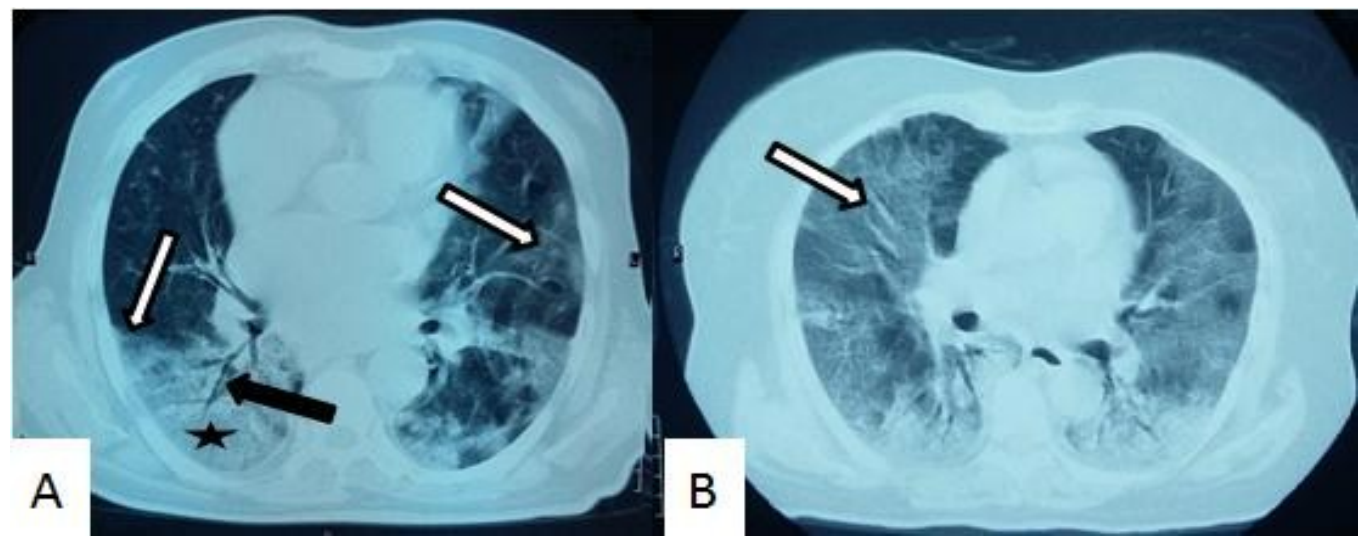

Figure (1): Axial CT chest; (A) showing Ground-glass opacity (white arrow), air Broncho-gram (black arrow), consolidation (black star); (B) diffuse areas of ground-glass opacity (white arrow).

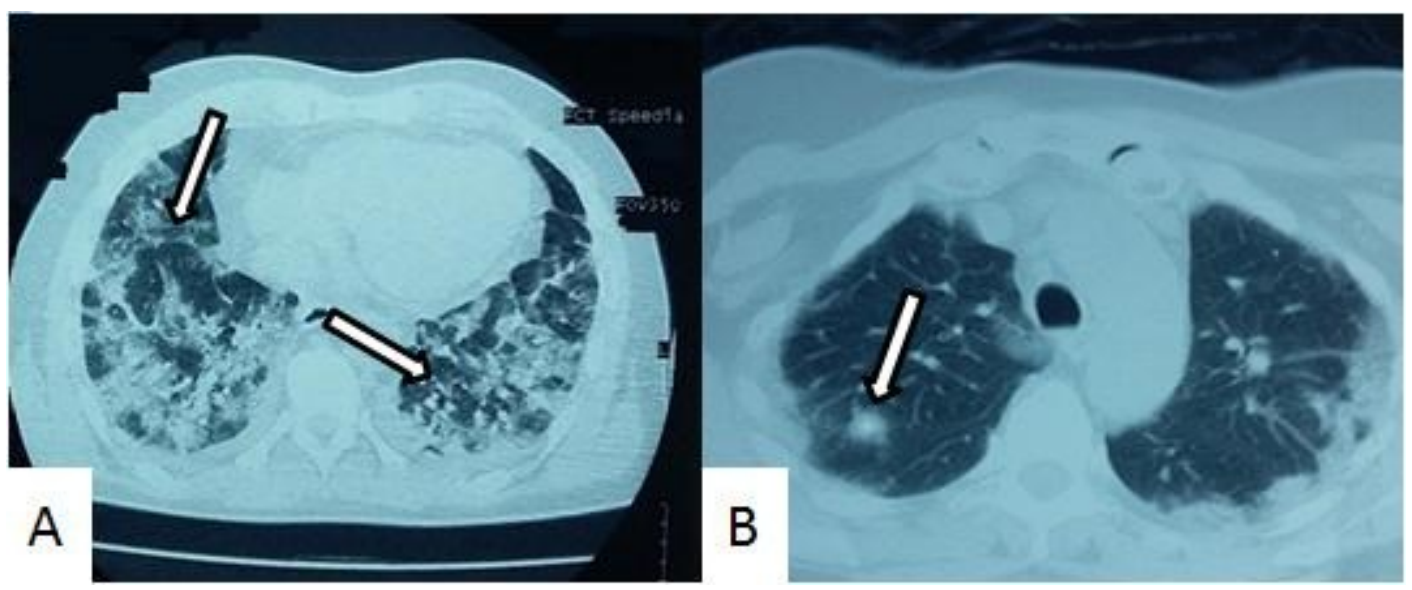

Figure (2): Axial CT chest; (A) showing Crazy paving pattern (white arrows); (B) halo sign (white arrow).
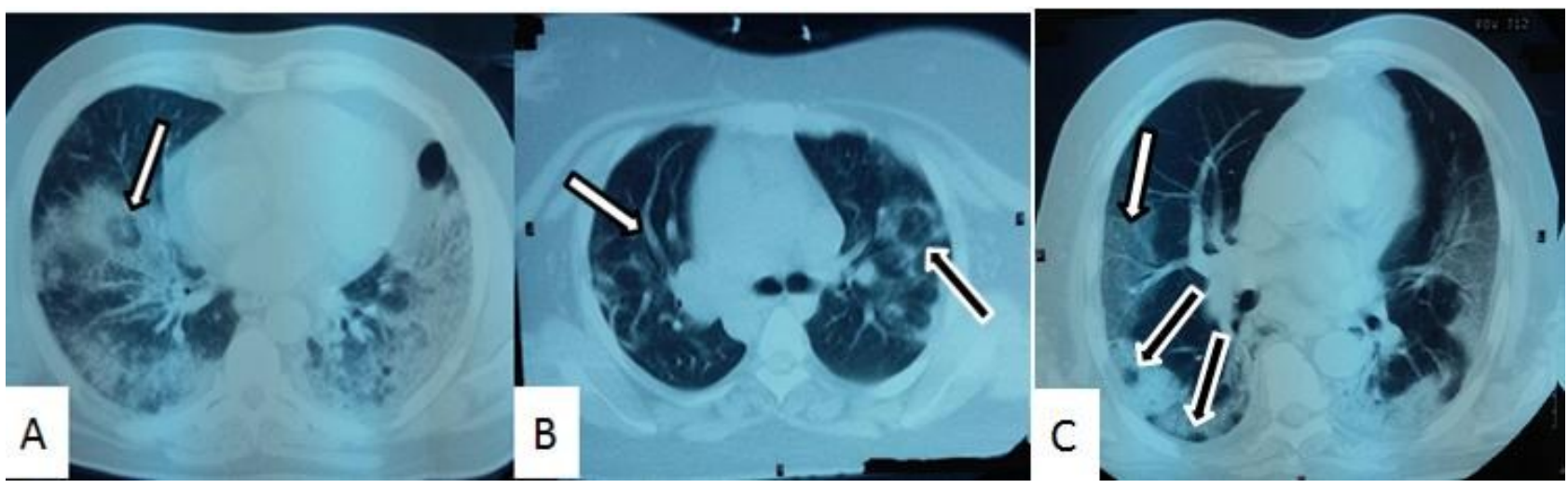

Figure (3): Axial CT chest; (A) Revers halo sign (white arrow); (B) Revers halo sign (black arrow), vascular thickening (white arrow); (C) ground-glass opacity (white arrow), Rt subpleural opacity with vacuoles (black arrows) 


\section{DISCUSSION}

This is a descriptive, case series study that has been carried out on 56 patients, 31 (55.4\%) females and 25 (44.6\%) males. Their ages range from 28-88 years $(62.79 \pm 11.3)$. $31(55.4 \%)$ were in-patient, while $23(41.1 \%)$ were out-patient. Non-contrast chest CT was performed for all patients. In this study, clinical manifestations and chest-CT findings of patients were studied. Most clinical presentations were similar to other studies (Mohamed et al., 2020; Heshui et al., 2020). The current study's results were fever $94.6 \%$, dyspnea $89.3 \%$, and cough $85.7 \%$. Two-thirds of patients complained of headaches, and about $45 \%$ declared a sore throat. Other symptoms, including nausea and vomiting, occurred only in $10 \%$ of the studied population.

In the present study, about $80 \%$ of patients had a comorbid disease, where diabetes was the more frequent comorbidity $69.6 \%, 53.6 \%$ were hypertensive, and approximately a quarter of the studied population had a triple disease (diabetes, hypertensive, and heart disease). Only $20 \%$ of patients had no chronic disease. This result is similar to a study by (Mohamed et al., 2020), where the most frequent comorbidity was diabetes, followed by hypertension. Heshui et al., (2020) concluded that; the risk factors for COVID-19 were old age and comorbid diseases such as diabetes, chronic pulmonary disease, and other chronic illness.

Non-contrast chest-CT plays an important role in the diagnosis of suspected cases of COVID-19 infection. Some studies revealed that the sensitivity of chest CT in diagnosing COVID-19 was 98\% (Hani et al., 2020; Carotti et al., 2020; pan et al., 2020). In addition, some literature has advised chest CT scan as an initial diagnostic investigation in epidemic areas (Ai et al., 2020; Xie et al., 2020; Heshui et al., 2020). The early control of a possible spread of the disease can be achieved by quick diagnosis, with the use of chest CT for the diagnosis of viral pneumonia, and thus the timely isolation and treatment of suspected cases ( $\mathrm{Li}$ and Xia 2020). A study by Li and Xia (2020) demonstrated that chest CT had a low rate of missed cases of COVID-19 (3.9\%), and therefore can be used as a standard technique for COVID-19 diagnosis. Even though CT features of COVID-19 are non-specific, the presence of these findings in patients with no symptoms or patients with mild respiratory symptoms is alarming in the setting of a pandemic, especially if there is no superior alternative for diagnosis (Rubin et al., 2020).

The common findings observed on chest-CT imaging of patients with COVID-19 were: ground-glass opacity GGO, consolidation, vascular enlargement, interlobular septal thickening, air bronchogram, and air trapping. These patterns are similar to $\mathrm{CT}$ patterns of Severe Acute Respiratory Syndrome (SARS) and Middle East Respiratory Syndrome (MERS) and caused by interstitial and alveolar pulmonary edema and injury ( $\mathrm{Li}$ and Xia 2020).

In the current study, ground-glass opacities were present in all studied patients $100 \%$, vascular thickening noted in $88 \%$, consolidation was found in $71.4 \%$ of the studied population. Interestingly, crazy paving patterns and vascular signs were found in an almost equal percentage of studied cases, $57 \%$, and $57.1 \%$ respectively. The study of (Li and Xia 2020) had shown CT findings of COVID-19 that are different from $\mathrm{CT}$ findings of SARS and MERS which are reversed halo signs and halo signs. In this study reverse halo signs were observed in $34.5 \%$ and halo sign were found in $34 \%$ of studied patients.

In previous studies, multifocal involvement was more frequent than uni-focal involvement (Li and Xia 2020; Heshui et al., 2020). In the current study, bilateral affection was found in $98.2 \%$, while in $76.8 \%$ of patients, all lobes involvement was noted. 
The results of this study suggest that the percentage of female patients is greater than male patients and patients with comorbidity are more likely to develop symptoms. Clinical presentation and chest CT manifestation are similar to those mentioned in the literature.

For positive COVID-19 patients, imaging sets up baseline pulmonary conditions and assists recognize primary cardiopulmonary pathologies that can help in determining the degree of risk for clinical deterioration $(\mathrm{Ru}-$ bin et al., 2020). Imaging is recommended to evaluate the progression of COVID-19 or secondary cardiopulmonary pathologies such as heart failure or pulmonary embolism that could be due to myocardial injury secondary to COVID-19 (Rubin et al., 2020). CT-chest may potentially have new roles by launching the response of treatments or differentiate patients who are more likely to respond to new forms of treatment (Rubin et al., 2020).

In the current study, there are several limitations. Firstly, the study had a relatively small number of patients (56 patients), all studied participants were symptomatic, and all of them were adults, and no children were involved. Further studies are required involving a larger number of patients, an asymptomatic population, and all age groups.

Secondly, the study only analysed the clinical manifestation and chest CT findings at first presentation, follow-up images are recommended in further researches to study disease progression and recovery signs. Finally, due to the unavailability of (RT-PCR), it is not included in this study, and WHO guidelines regarding diagnosis in the absence of (RTPCR) are followed.

\section{CONCLUSION}

Covid-19 is an emerging global health problem; rapid diagnosis is an important issue for tackling the spread of the disease. CT chest along with symptoms play an important role (C) 2020 The Author(s). This open access article is distributed under a CC BY-NC 4.0 license. ISSN: online 2617-2186 print 2617-2178 in Covid-19 diagnosis in the event of RTCRP unavailability. This case serial study describes the common symptoms and CT-pattern among 56 patients in Al-Bayda city $\backslash$ Libya, the findings are similar to some regional and international findings. This paper might help raise awareness among local physicians and radiologists, and possibly be used as a baseline for future related research.

\section{ABBREVIATIONS}

CT: Computerized Tomography. COVID-19: Coronavirus Disease-2019.

GGO: Ground-Glass Opacities

MERS: Middle East Respiratory Syndrome. RT-PCR: Reverse Transcriptase Polymerase Chain Reaction.

SARS-Cov-2: Severe Acute Respiratory Syndrome Coronavirus.

WHO: World Health Organization

\section{REFERENCES}

Ai,T., Z. Yang, H. Hou, C. Zhan, C. Chen, W, Lv , Q. Tao, Z. Sun, L. Xia.(2020) Correlation of chest CT and RT-PCR testing in coronavirus disease 2019 (COVID-19) in China: a report of 1014 cases.Radiology 296(2):E32-E40.doi: 10.1148/radiol.2020200642.

Bernheim ,A., X. Mei, M,Huang, Y. Yang, Z.A. Fayad, N. Zhang, K. Diao, B. Lin, X. Zhu, K. Li, S. Li, H. Shan, A.Jacobi, M. Chung.(2020). Chest CT Findings in Coronavirus Disease 2019 (COVID19): Relationship to Duration of Infection. Radiology. 295(3):685691.https://doi.org/10.1148/radiol.2020 200463.

Carotti, M., F. Salaffi, P. Sarzi - Puttini, A. Agostini, A, Borgheresi, D.Minorati, M. Galli, D. Marotto, A. Giovagnoni. (2020). Chest CT features of coronavirus disease 2019 (COVID-19) 
pneumonia:key points for radiologists. La radiologia medica 125(7) 636-646.

Hani, C., N.H. Trieua, I. Saaba, , S. Dangearda, S. Bennania, G. Chassagnona, , M.-P. Revel (2020). COVID-19 pneumonia: A review of typical CT findings and differential diagnosis. Diagnostic and interventional Imaging. 101 (5) 263268.

Heshui, S., X.Han, N. Jiang, Y. Cao, O. Alwalid, J. Gu, Y. Fan, C. Zheng (2020). Radiological findings from 81 patients with COVID-19 pneumonia in Wuhan, China: a descriptive study. The Lancet Infectious. 20 (4) 425-434.

Ibrahim, O.A.M.(2020).Medical record 3172020.Baida City: Asalam Hospital.

Kim, H., Hong, H., and Yoon, S. H. (2020). Diagnostic Performance of CT and Reverse Transcriptase Polymerase Chain Reaction for Coronavirus Disease 2019: A Meta- Analysis. Radiology,296 (3)E145-E155.

Li, Y., and Xia, L., (2020). Coronavirus Disease 2019 (COVID-19): Role of Chest $\mathrm{CT}$ in Diagnosis and Management. American Journal of Roentgenology. 214 (6) 1280-1286.

Mohamed, Y., G., Mohamed, F., Y., M., Medisoglu, M., S., and et al (2020). Clinical and chest CT presentations from 27 patients with COVID-19 pneumonia in Mogadishu, Somalia: a descriptive study. Egyptian Journal of Radiology and Nuclear Medicine. (51): 184.

Fang,Y., H. Zhang, J. Xie, M. Lin, L.Ying, P.Pang, W. Ji.(2020) Sensitivity of chest CT for COVID-19: comparison to RT-PCR. Radiology. https://doi.org/10.1148/radiol.20202004 32
Pan, F., C.Zheng, T, Ye1,, L. Li, D. Liu, L. Li,R. L. Hesketh, L. Yang. (2020). Different computed tomographypatterns of Coronavirus Disease 2019 (COVID19) between survivors and nonsurvivors. Scientific Reports. 10: 11336

Rubin, G., D., Ryerson, C., J., Haramati, L., B., and et al, (2020). The Role of Chest Imaging in Patient Management during the COVID-19 Pandemic: A Multinational Consensus Statement from the Fleischner Society. Radiology. 296 (1) 172- 180.

Sabri, Y.Y, A.A. Nassef, I. M. H. Ibrahim, M. R. Abd El Mageed ,M. A. Khairy. (2020). CT chest for COVID-19, a multicenter study - experience with 220 Egyptian patients. Egyptian Journal of Radiology and Nuclear Medicine. (51): 144.

World Health Organization. (2020a). Coronavirus disease (COVID-19) pandic.

https://www.who.int/emergencies/disea ses/novel-coronavirus-2019. Accessed Novembr 17, 2020.

World Health Organization. (2020b)Use of chest imaging in COVID-19: a rapid advice guide. Geneva: (WHO/2019nCoV/Clinical/Radiology imaging/2020.1). Licence: CC BY-NCSA 3.0 IGO.

Mohamed,Y.G., M. F. Y.Mohamud, M. S. Medişoğlu, I.Y.Atamaca, I. H. Ali. (2020). Clinical and chest CT presentations from 27patients with COVID-19 pneumonia in Mogadishu, Somalia: a descriptive study. Egyptian Journal of Radiology and Nuclear Medicine. (2020) 51:184 https://doi.org/10.1186/s43055-020$\underline{00302-2}$ 
Xie X., Z.Zhong,W.Zhao , C Zheng, F.Wang, J.Liu. (2020). Chest CT for typical2019-nCoV pneumonia: relationship to negative RT-PCR testing. Radiology Published online February 12, 2020. doi: $10.1148 /$ radiol.2020200343

Zheng Ye.,Y.Zhang, Y. Wang, Z. Huang,B. Song. (2020). Chest CT manifestations of new coronavirus disease 2019 (COVID-19): a pictorial review. European radiology. 30 (8)4381-4389. 


\title{
العلامات السريرية وإنماط الاثعة المقطعية الصدرية ل 56 مريض بذات الرئة الناتجة عن كوفيد-19
}

\author{
علا عبد الرحمن ابراهيم"، ايناس مصطفى الهاين، وليد المبروك سعيد ووديان مصطقى عبد الصادق \\ قسم الاشعة التشخيصية، كلبة الطب البثري، جامعة عمر المختار، البيضاء-لبييا.

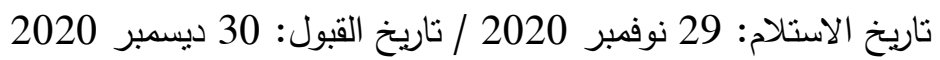 \\ https://doi.org/10.54172/mjsc.v35i4.334:Doi
}

المستخلص : منذ إعلان جائحة كوفيد المستجد-19، ازداد اهتمام أطباء الأشعة والباطنة بشأن كيفية تشخيصه بشكل كبير . تعتبر مسحة الأنف المرجع الرئيسي لنتخيص الالتهاب الرئوي الناتج عن فيروس كوفيد-19، لكن توفرها والمعدل السلبي الخاطئ واعتمادها علي خبرة الممارس والوقت المستقطع حتى ظهور النتيجة ،جعل التصوير المقطعي أكثر تفوقًا في تشخيص الالتهاب توني الرئوي الناتج عن كوفيد المستجد-19، و هذا ما أتبع في مدينة البيضاء- ليبيا، حيث تم الإبـاغ عن أول حالة انتشار محلية في 30 يوليو 2020، تلاهـا ارتفاع كبير في عدد الحالات، الذي تطلب التعرف على السمات السريرية الرئيسية ونمط التصوير المقطعي للالتهاب الرئوي بسبب كوفيد-19 لزيادة الوعي بين الممارسين وأخصائي الأشعة المحليين وتسهيل التشخيص السربع، وهذا هو الهدف الرئيسي لهذه الدراسـة. أجريت هذه الدراسة الوصفية لسلسلة الحالات في المستشفى المركزي لمدينة البيضاء في لئي لبييا في الفترة مـا بين 11 أغسطس إلى 21 سبتمبر 2020، وشملت 56 مريضًا (31 أنتى و 25 ذكردًا). نتراوح أعمارهم بين

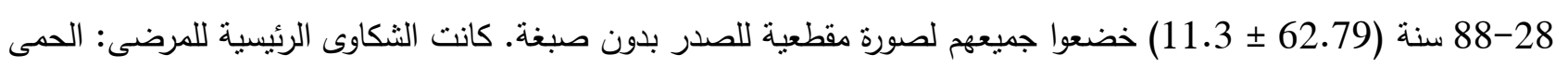

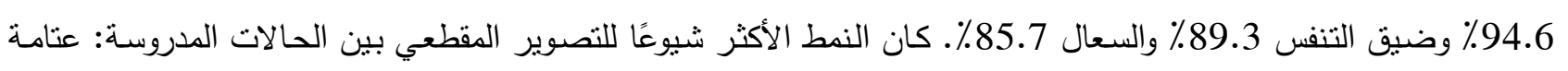

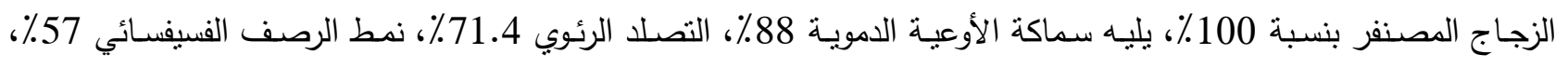

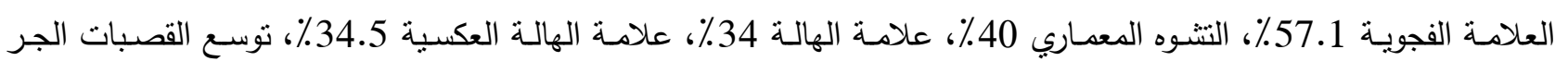
16٪. أخيرًا، يلعب التعرف على أنماط التصوير المقطعي للالتهاب الرئوي بسبب كوفيد-19 دورًا مهمًا في الاكتشـاف المبكر وبالتالي تطبيق احترازات العزل والعلاج. كما يمكن استخدام نتائج هذه الدراسة كلبنة أساس لمزيد من الابحاث في المستقبل. الكلمات المفتاحية: التهاب رئوي بسبب كوفيد المستجد-19، كوفيد المستجد-19، كوفيد المستجد-19 ليبيا ،التصوير المقطعي للصدر ، عتامه الزجاج المصنفر • لمفئ. 